Journal of International Development

J. Int. Dev. 27, 816-834 (2015)

Published online in Wiley Online Library

(wileyonlinelibrary.com) DOI: 10.1002/jid.3112

PRE-PROOF VERSION

\title{
The Ebola Crisis and post-2015 Development
}

\author{
Melissa Leach \\ Institute of Development Studies
}

\begin{abstract}
This article argues that the recent Ebola crisis is the result of structural violence, as interlocking institutions have produced interlaced inequalities, unsustainabilities and insecurities. These have underlain the vulnerabilities in Sierra Leone, Liberia and Guinea through which a disease outbreak became a major health, social and economic crisis and the local fears, distrust, rumours and resistance that magnified it further. Articulating this analysis of Ebola with broader perspectives, the case is made for a reframing of post-2015 development as transformational politics towards equality, sustainability and security, enabling people to realise well-being
\end{abstract}

\section{Introduction}

The Ebola crisis which has unfolded in West Africa since December 2013 is a global emergency and a set of personal tragedies. With over 25,000 cases (WHO 2015) it is the worst Ebola outbreak in history and as Margaret Chan of the WHO put it: 'the most severe acute public health emergency seen in modern times. Never before in recorded history has a biosafety level four pathogen infected so many people so quickly, over such a broad geographical area, for so long' (WHO 2014a). Equally - although belatedly and partially - the epidemic has attracted an unprecedented level of international, public and media attention. Yet over a year from the outset, as infection rates slow - if intermittently - and the focus of epidemic response shifts to a second phase from slowing transmission to ending the epidemic, it is time for some deeper reflection on the implications of the Ebola crisis for development.

This article argues that the depth and extent of the crisis in the three most affected countries Sierra Leone, Liberia and Guinea, united as the Mano River Union - are the result of 'structural violence' (Galtung 1969) in the sense of an interlocking set of institutions which produce interlaced inequalities, unsustainabilities and insecurities (see also Wilkinson and Leach 2014). 
Development discourses and practices over the last few decades, and associated patterns of aid and investment in health but also beyond it have been part of this process. The Ebola crisis provides a lens through which to reflect on why outbreaks become disasters in some places but not others, and on the vulnerabilities of some people and places but not others in a globallyinterconnected world.

The article begins by outlining some key parameters of the Ebola crisis, and narratives about it both powerful narratives that have dominated the international debate and response, and alternatives. The latter point towards the need to pay greater attention to the underlying causes of the crisis, and to understand these in terms of structural violence. The following sections elaborate this argument, outlining patterns and processes in the region that have produced inequalities of various kinds, problems of environment and non-sustainability as locally felt, and problems around conflict and limited post-conflict recovery, and relating these to the Ebolarelated events of 2014. These three areas of challenge, the paper suggests, are interlaced, and collectively underlain by a failure of development to support inclusive health, governance and livelihood systems, and the institutions to sustain them.

As global attention turns to a post-Ebola recovery plan (eg. BBC 2015), a better understanding of the causes of the crisis can inform what it would take to re-build health and related systems so that they provide greater resilience to such crises in the future. This in turn suggests a more fundamental need to reframe development - in the region and beyond - as transformational politics towards greater equality, sustainability and security. Such transformational politics must be locally grounded but globally embedded and universally practiced, emphasising inclusion of the perspectives and priorities of the most marginalised. While the post-2015 agenda and the SDGs offer promise, moving the debate in the right directions, more attention needs to be given to the interlacing of dimensions and to pathways to progressive change that enable people to realize well-being and justice in terms that make sense to them.

The article thus articulates an analysis of the Ebola crisis and its causes - based not on new primary data but on a collation of recent reports and media analysis of Ebola, with wider regional literature - with a far broader argument. This clearly presents challenges of conceptual elucidation and evidence in a short piece, and apologies are due in advance if it appears overreaching. However post-2015 and the Ebola crisis each offer unprecedented moments for some fundamental thinking about development futures. As an engaged analyst with longstanding and personal research and policy commitments to both sustainable development and health agendas, both globally and locally in Guinea, Sierra Leone and Liberia (eg. Fairhead and Leach 1996, 1998, 2003, 2007; Dry and Leach 2010; Leach and Fairhead 2007, Leach et al 2010;) it would be shirking responsibility not to draw these together.

\section{The Ebola crisis and narratives about it}

The origins of the recent West African Ebola outbreak can be traced to the village of Meliandou in the forest region of south-east Guinea, where in December 2013 a two year old child, Emile 
Ouamouno, contracted an infection from likely contact with a bat. The mysterious fever spread to his family members, to an under-equipped rural health centre, and then through a health worker's funeral, and related kin and trading networks, to others, in this region of high mobility and sociability. By March $22^{\text {nd }} 2014$, when tests confirmed the Zaire Ebola virus strain (WHO 2014b), Emile became famous as 'patient zero' in an epidemic that was already growing fast, crossing borders into Sierra Leone and Liberia, and entering their towns and cities. By the time the international community belatedly responded, the epidemic was already out of control. At its height in September-October, it was growing exponentially - in Sierra Leone at a rate of around 250 new cases per week, and an epidemic doubling time of around 30 days (WHO Ebola Response Team 2014).

Aiming to 'bend' by now frighteningly exponential epidemic curves, international agencies, NGOs and foreign governments - the UK leading in Sierra Leone, France in Guinea, and the US in Liberia - poured resources into a series of emergency response activities, variously including building Ebola Treatment Units/Centres and Community Care Centres, supplying volunteer health workers, public health and educational messages, and developing experimental pharmaceutical treatments and vaccines. By December, the curves had started to flatten, initially in Liberia and then in Sierra Leone and Guinea. Yet by the time of writing, in April 2015, the epidemic had claimed over 10,500 lives in Guinea, Sierra Leone and Liberia, with over 25,000 cases overall - including a handful in neighbouring West African countries, Europe and the US (WHO 2015). Ongoing small outbreaks in Sierra Leone and Guinea signal real difficulties in bringing the epidemic smoothly to an end.

The crisis unleashed by Ebola is not just epidemiological, but also of social and economic fabric. Ebola has of course represented personal tragedy for the many rural and urban women, men and children who have lost loved ones, and been left without parents, families and neighbours. It has been a tragedy for community fabrics, causing people to fear the social basics of shaking hands, hugging and making love, striking hardest at those who do the social and moral good of caring for the sick well and burying the dead respectfully and appropriately - two of the key transmission routes (Richards et al 2014), and leaving survivors with difficulties in reintegration. Consequences of the epidemic include livelihood tragedies as food supplies and trade routes have broken down and employers - such as mining companies - packed up and left, and devastation to national infrastructure and economy as all attention turned to fighting the disease. 'Post Ebola recovery' is likely to be a major and slow process.

As the crisis has garnered world attention, many narratives have circulated amongst international agencies and in public and media commentary, with different emphases. One storyline links the epidemic to a zoonotic spillover event in a poor, out of the way place in an uncertain, and environmentally-degrading world. The notion that rapid deforestation combined with poverty is newly bringing people, virus-carrying bats and infected wildlife into contact has been pervasive (Quammen 2014, Bausch and Schwartz 2014, McCoy 2014), and underlay a focus on 'avoiding bushmeat consumption' in early Ebola information campaigns (Samb and Toweh 2014). As I explore later, this narrative is highly misleading in its misrepresentation of human-environment relations. Moreover while a focus on animal-human 
transmission is relevant for understanding the initial spillover event that triggered the outbreak, since then it has been entirely-human-human.

A second storyline blames the epidemic on local 'cultural' beliefs and practices, including those contributing to transmission - burials and funerals, especially of high-ranking officials of the region's initiation societies, are held to account for a high proportion of those cases occurring in community settings (eg. Grundy 2014) - and those underlying the resistance of local populations to outbreak control measures. Villages barricaded-out and stoned control teams, removed patients from health centres, and refused to enter them fearing them places of killing and bodypart theft, while rumours have circulated that the Ebola virus was not real, but an international or government plot. Such instances of resistance have continued throughout the epidemic. As Ebola Virus Disease (EVD) became 'Ebola Panic Disease', it became harder to bring under control, contributing to the scale of the unfolding disaster. Attributing such beliefs and practices to culture, superstition or just plan ignorance has underlain top-down approaches to 'correcting misinformation' and behaviour change.

A third narrative scales up local transmission into a classic 'global outbreak narrative', seen around so many other emerging infectious diseases, in which a disease 'out of Africa' threatens a world of mobile people and microbes, reaching its tentacles out to affect the powerful global North (Wald 2008, Dry and Leach 2010). This is the narrative that, fuelled by the handful of cases that occurred in the US and Europe - finally stirred publics and politicians into action, mobilising a large-scale and militarised international response and belated investment in experimental treatments and vaccines.

There is truth in all of these narratives, but they tell very different stories, from different positions and interests, justifying different kinds of action. In common, though, these accounts sit uncomfortably with the experiences and perspectives of people living in the rural and periurban settings of Sierra Leone, Liberia and Guinea. Their multitude of less-heard views can be captured in two further, alternative narratives about the Ebola crisis. One emphasises and legitimises people's own knowledge, expertise and practical experience in dealing with matters of life, death and health, supported by a variety of community-level institutions. As documented in rapid-response anthropological and participatory research and reflection (www.ebolaanthropology.net), caring, burial and mobility practices have deep logics in the region's everyday social fabric, and yet communities have been quick to learn and adapt these to reduce Ebola transmission. Community learning and control, with appropriate external support, may well prove to have been the key factor that turned this epidemic around - as indeed it has been in curbing much smaller Ebola outbreaks in Central and East Africa (Hewlett and Hewlett 2008).

A second alternative narrative, and the focus of this paper, tells of the structural violence which has underlain the explosion of an Ebola outbreak into a crisis of such dramatic proportions. The term structural violence refers to the way institutions and practices inflict avoidable harm by impairing basic human needs. The term dates back at least as far as Johan Galtung's (1969) usage to describe the effects of negative social structures characterised by poverty and social inequality, including racism and gender inequality. As a contribution to the study of social 
oppression, the term acknowledges how damage is exerted unequally, systematically, indirectly, and often in a manner which comes to be taken for granted. The resulting harms include those associated with health; thus Gilligan defines structural violence as 'the increased rates of death and disability suffered by those who occupy the bottom rungs of society, as contrasted with the relatively lower death rates experienced by those who are above them' (1997:194). The extensive work of Paul Farmer $(2003,2004)$ has drawn the concept firmly into medical anthropology, extending it to discuss 'adverse events' including genocide, human rights violations and epidemics, and more generally, to drive home how inequitable socio-political and economic structures are at the root of disease. In Farmer's work, the structures at stake include global political and economic systems, and the institutions and practices of states, corporations and others within these.

In similar terms, this article argues that the Ebola crisis has emerged from the meeting of longterm economic, social, technical, discursive and political exclusions and injustices. Put another way, an interlocking of institutions has contributed to longer-term, and interlaced, inequalities, unsustainabilities, and insecurities. Each of these is a vector of structural violence which together, as the next sections explore, help to explain the region's extreme vulnerability to crisis, and give logic to the rumours and resistance that have magnified it. This is in a set of localities long interconnected with a global world through political and economic relations, and more recently with 'development' in its narrower sense of the discourses and practices of an aid industry. The paper suggests that the latter have been partly culpable in producing, or at least failing to tackle, structural violence.

\section{Ebola, development and structural violence}

This section, then, elaborates this thesis that the Ebola crisis is a manifestation of structural violence, in which a combination of institutions have contributed to longer-term inequalities, unsustainabilities and insecurities. A focus on the Ebola crisis provides a lens onto the importance of these issues in emerging debates about development, in its wider sense of progressive economic, social and political change. While each of these dimensions of structural violence is considered in turn, a core argument that will emerge is that they are interlaced in crucial ways, which a focus on the Ebola crisis helps to reveal.

\section{Inequalities}

Ebola has been spreading through a region that some commentators have depicted as isolated and backward (Bausch and Schwarz 2014), but has actually been long and deeply-interconnected with a global world. The Sierra Leone -Liberia-Guinea border region had a central place in the Atlantic slave trade (Green 2014) and vibrant trans-West African trading empires through the eighteenth and nineteenth centuries (Fairhead et al 1999), to importance in supplying labour and commodities (rubber, timber, cocoa, minerals) to British, French and Americo-Liberian powers (Fyfe 1962, McGovern 2012, Fairhead and Leach 1996, Clower et al 1966). While these colonial histories vary, they have in common the extraction of rich resources to the major benefit of foreign and some national economic elites. Interventions often yielded little benefit to - and 
indeed exploited, dispossessed and did violence to - local populations, relying on and perpetuating economic and political inequalities.

In the decades up to and following Independence, uneven development associated with natural resource extraction continued across the countries of the Mano River Union. In Sierra Leone, for instance, the large scale iron ore mine at Marampa first established in 1930 operated as an enclave with few linkages to other areas of the economy or society. In the 1970s, alluvial diamond extraction became the mainstay of the patrimonial political economy of Siaka Stevens, notorious for its rent-seeking, corruption and related extreme inequalities (Reno 1995). In Guinea, Sekou Touré's 1958-1984 regime fostered a pattern of intrusive state socialism that largely failed to build rural livelihoods, while concentrating resources in the hands of politicoethnically favoured Manding elites, marginalising other groups - including those of the Forest Region where the Ebola outbreak started. These roots of uneven development laid the ground for the further inequalities created in the 1980s period of donor-led structural adjustment and economic reform, when Mano River Union states scaled back on the resource-related patronage they could dispense, concentrating this even more narrowly on particular (often ethnicallyfavoured and urban) groups.

Amidst present-day neoliberal capitalism some key elements of this pattern have continued, fostered by a major extractive resource boom. Now understood to overly a major geological beltway, the region is optimistically expected to furnish an estimated $40 \%$ of global iron ore exports within a decade. The influx of large multinational mining companies such as Rio Tinto, London Mining and Arcelor Mittal, supported by World Bank and IMF -influenced government policies to encourage large-scale foreign direct investment, have brought extraordinary economic growth rates - Sierra Leone's economy grew more than $21 \%$ in 2013 . Yet this has come with costs. This exemplar of 'Africa rising' in economic terms has not been matched by effective governance and institution-building, and several projects have been beset by major corruption scandals (Dowden 2014). For instance the vast Simandou mine in south-east Guinea under development by Beny Steinmetz Group Resources (BSGR) was closed in 2013 after FBI investigations, and so far nothing has been dug. Even where mining in the region has progressed, local benefits in employment and infrastructure have been few, and targeted narrowly to serve mineral operations (Davies 2012). External mining interventions have fuelled distrust and suspicion by local populations of foreign and government interventions, as they have received so few benefits from the mining resource boom (Allouche 2015). Meanwhile large scale operations have displaced people and their livelihoods, and squeezed out artisanal producers (Maconachie 2012).

Similarly in the agriculture and forestry sectors, a wave of large-scale foreign investments to serve commercial export food crop, biofuel and now carbon credit markets has brought profit to foreign and local elites, but often at the expense of smallholder rights and livelihoods, undermining rural institutions (Tran 2013, Pearce 2012).

For many in the region, Ebola and the international response to it was feared as a logical extension of such extractive and sometimes corrupt foreign and elite practices. This underlies 
the many rumours that have circulated, amongst local populations who as Epstein (2014) puts it 'in their desperation, have .... begun to see plots and conspiracies everywhere'. In some areas of Guinea, people believe Ebola to have been introduced by white people who have mineral resource interests, with the complicity of the government, for the sole purpose of destroying their communities (Faul 2014). Following the Simandou scandal, some attributed the supposed introduction of Ebola in Guinea Forestiere as Beny Steinmetz's revenge against the expropriation of his mining rights. Other widespread rumours attribute Ebola to 'white sorcery', drawing on longstanding idioms extending back to the slave trade that hold those who accumulate extraordinary wealth to have done so through nefarious practices that draw on supernatural power (Bolten 2014, Shaw 2002).

Such fears have also applied to foreign outbreak control teams, who - with their alien-ness magnified by space-suit-like protective suits - have been interpreted as extractors of human resources - body parts, blood, lives - to serve mysterious but assumed-powerful international markets. In this way, long histories of extractive development and their legacy of fear give logic (if not exoneration) not just to people's early avoidance of treatment units, but also to dramatic and violent incidents such as the stoning of MSF vehicles and the orchestrated killing of health workers and journalists in the village of Womey in Guinea (Abby 2014). In this context fears of sorcery and related body-part theft circulate as a longstanding idiom, a way of making sense of the extraordinary wealth and power that accrues to a few. The supposed sorcery of today's Ebola outbreak control teams finds a logic in memories and discourses of the slave trade and before - grounded not in traditional myths or timeless culture, but history and political economy (Shaw 2002).

This pattern of political-economic relations also has broader consequences that have contributed to the Ebola crisis. It has fuelled economic inequalities, enabling high incomes and wealth for some, but leaving most without formal employment and seeking precarious rural or urban livelihoods. Household survey data for 2011 reveal large income gaps in Guinea, Liberia and Sierra Leone - in each country the top $20 \%$ earning $44-46 \%$ of national income, compared with 20-22\% for the bottom 20\% (World Bank 2015), yet are likely to underestimate them, missing semi-illicit incomes amongst economic elites at the top and minimal, informal incomes at the bottom.

Recent global debates also highlight both the rise and significance of inequalities within countries. There is powerful evidence of rising inequalities across Europe, now at their highest levels since the 1920s, as well as in 'emerging power' countries such as China and India (Piketty 2014). The debates, while too large and rich to do justice to here, nevertheless highlight some key points relevant to the Ebola crisis. Recent debates highlight why this matters - why poverty matters for sure, but why just building the assets and upward mobility of the poor isn't enough if the gaps are not also addressed (Oxfam 2014). Greater inequality is associated with poor outcomes across many social and health indicators, from life expectancy to trust and social mobility (Wilkinson and Pickett 2009). The mechanisms are social, psychological and ideological, and linked centrally to the ways that people internalise hierarchies - so that inequality 'gets under the skin'. 
Inequalities of income and assets, in these countries as elsewhere, intersect with 'horizontal' inequalities - across gender, ethnicity, location, and contextual attributes of social status - in shaping patterns of disadvantage and advantage, in place-specific and nuanced ways (Stewart 2002, Arauco et al 2014). In the region, inequalities faced by women and young people who are denied access to land, property and rights over their own and other's labour by state and customary institutions are part of these inequalities (Richards 1996) which keep some people in deeply precarious positions.

This has in turn had direct consequences for the dynamics of the Ebola crisis. For instance while the Ebola epidemic has had rural hotspots and pulses, it has crucially 'gone urban', powering through growing urban and peri-urban areas. These are places whose massive growth is at least partly a legacy of neglected rural and agricultural development, as well as dislocation and displacement due to war. They are also places of high dynamism and innovation, where people are able to pursue a diversity of livelihood strategies and occupations, often continuing to interact with social and economic networks in rural areas. The result is a high density of population, high mobility, and major challenges in planning and the provision of essential services - all conditions conducive to rapid Ebola transmission (Waldman 2015).

Not surprisingly perhaps, it was the deep rural areas that managed to isolate themselves from such 'development' that successfully isolated themselves from Ebola, drawing on still-intact chieftaincy and local structures to enact bye-laws to prevent kin from infected areas entering. Malema Chiefdom, where I lived in the late 1980s, survived Ebola as it survived the Sierra Leonean civil war - and very likely the smallpox epidemics of the 1970s - by withdrawing, and locally-managed quarantines.

There are also important, though not fully clear, interactions between economic and political inequality; between people's disenfranchisement in material terms, and their ability to stake voice and claims in political processes. One amongst many possible dynamics here concern how in countries of great material inequality, politicians resort to nationalism, sectarianism and identity, rather than economic policy, to secure mass support (Gilens and Page 2014). In West Africa, politicians often appeal to ethnic regionalisms. This has played strongly into the Ebola crisis. In Guinea, longstanding tensions between Forest Region peoples such as the Kissi and Toma, and Manding-dominated party in power, were re-ignited and expressed in a highly politicised response to the Ebola outbreak, and in Forest Region peoples' resistance to it fearing that state-supported outbreak control teams were spreading virus in a genocidal plot against them. In Sierra Leone the epidemic originated in the East, in the heartland of the Mendesupported Sierra Leone People's Party, currently in opposition to the All People's Congress with its longstanding support base amongst Temne people and others of the centre and North. Sectarian politics may partly have underlain both the central government's perceived slowness to intervene - casting the epidemic as a problem of the distant East - and later, popular fears, again, that outbreak control teams were spreading virus as part of a political genocide campaign. In such cases, we see a non-inclusive politics playing off horizontal inequalities against economic ones, in ways that can in turn fuel an epidemic crisis. 
Political-economic relations and development in recent years have also failed to build and sustain adequate health systems in the Ebola-affected countries. This has been a central cause of the crisis. Crucially, Ebola has transmitted fast through neglected health systems (Abramowitz 2014). Poor facilities in these centres have underlain that more than $10 \%$ of deaths have been of healthcare workers that these countries could ill afford to lose. The health care systems in these countries desperately lack - as Farmer (2014) put it 'stuff, staff and systems'. Even before Ebola, this lack led many people to avoid formal health care facilities - finding them too often with no drugs, nurses or useful knowledge and instead to resort to home care, traditional healers and informal vendors within their pluralistic understandings of disease and therapy (Ferme 2014, Leach et al 2008). As the Ebola outbreak hit, no wonder that people not in the habit of finding formal health facilities helpful were often reluctant to go to them, or see family members placed there.

The 'weakness' in health systems in the region needs to be seen not just as technical, but the result of particular political-economies of neglect - including those fostered by the aid system. These include 1980s and 1990s decades of aid conditionalities and structural adjustment reforms which hollowed out state services such as health and education. The politics of international aid during the Cold War contributed, as the West tolerated - or even propped up - despotic leaders such as Siaka Stevens who were allowed to undermine state services and appropriate aid revenues in return for cold war alliance. Direct aid to health followed in the 2000s, but often focused on particular diseases and health issues, often aimed at meeting Millennium Development Goal targets and achieving high profile and recognition in the process. Thus donor and NGO programmes have been 'vertically' targeted at HIV, malaria and mother and child health, but at the expense of the less glamorous task of building state capacity to train, retain and pay health staff, etc. Thus the recent aid focus on universal access hasn't been directed in ways that would build the resilient accessible networks of rural health and paramedicine that might have led rural people, in pre-epidemic contexts as well as now, to see hospitals and health centres as places of care - as opposed to ones to be avoided and sometimes resisted.

There have also been health system problems at the international level. Despite warnings that the epidemic was unprecedented and 'out of control' (MSF 2014) the reaction, especially from the World Health Organization, was disastrously ineffective. Poor communications, delayed visas and payments, and complacency meant that the agency called the first regional meeting on the disease three months after Ebola's detection and it was not until the end of August that it announced a roadmap for containing the outbreak (Gostin 2014). This late response reflects long-standing challenges in global health governance. The World Health Organization had been through dramatic restructuring and cuts as a result of reduced contributions after the financial crisis (Boseley 2014). Over time the political economy of aid and global health has meant that the WHO has increasingly become a technical organization, rather than one taking responsibility for health as a global public good (Gostin and Friedman 2014). 


\section{Sustainability}

Ebola is spreading through places where in a narrative of environmental blame, a story runs that it is farmers deforesting a landscape and exposing themselves to bats for the first time that caused the epidemic, and that avoiding bushmeat is a means of protection (McCoy 2014). Yet this, like many of the official truths about Ebola time - are inaccurate. People and bats have long co-habited in this ancient, anthropogenic forest landscape with its mosaic of forest, bush and savannah, shaped by settlement and farming, war and trade, and everyday social and ecological life. This is the sort of misinformation that is all too common in environment-development approaches that assume local people to do damage and so keep them out of forests now to be protected and separated from people for biodiversity, carbon or indeed now as viral reservoirs. As so much of my earlier work with James Fairhead showed (Fairhead and Leach 1996, 1998), such narratives justify people losing control over natural resources - despite longer histories of human-ecology interaction in enriched anthropogenic landscapes that have co-evolved with often sustainable livelihoods. That narratives of environmental blame and deforestation have suddenly been given new life by Ebola is deeply worrying, not least in obscuring attention to the more complex interactions between people, bats, landscapes and disease in patchy, anthropogenic landscapes that badly need to be understood and addressed. Misguided exhortations against eating bushmeat have not just denied people vital sources of protein and livelihood, but have contributed to the deluge of misinformation that has undermined local trust in what officials say about Ebola. Such gulfs between national and international science and policy understandings, and people's experiences on the ground (cf. Fairhead and Leach 2003), constitute a form of cognitive violence which is itself part of the structural violence being described here.

Catastrophist environmental narratives have a lot in common with catastrophist outbreak narratives; they tell only selective versions of complex stories, and ones that can justify problematic and repressive forms of intervention. However the key point I want to make here is that both sustainability problems and challenges in moving forward on them are deeply interlaced with questions of inequality.

There is rising scientific evidence of pressures on our planet. Powerful scientific and political discourses - such as those around planetary boundaries - suggest that business as usual is not an option; there is a need to bend the curve of carbon emissions and other forms of environmental degradation, and urgently, to keep societies within a 'safe operating space' for humanity (Rockstrom et al 2009, Steffen et al 2015). Yet such pathways must also address questions of distribution in who pollutes, where and how, and as climate change highlights, this is highly uneven (Leach et al 2013).

Inequalities at multiple scales contribute to unsustainability, and make it more difficult to build sustainable paths. For instance, they make co-operation more difficult - whether within societies, or globally - and environmental issues are ones where co-operation around 'public' goods is vital (Baland et al 2006). Institutions can enable important forms of co-operation across multiple scales (Ostrom 1990). Local co-operation has been the bedrock of effective community 
forest, water and farm resource management in Sierra Leone, Liberia and Guinea as elsewhere (Leach 1994, Fairhead and Leach 1996). However building a sense of common interest to protect 'national' resources - whether in land, carbon, biodiversity or forest reserves - has proved more challenging given histories of distance and conflict between local populations and those seen to be enriching themselves from the nation's rich resources (see Maconachie 2008).

There are also many ways in which environmental degradation and growing resource pressures contribute to poverty and to inequality. Environmental shocks and stresses, mediated by socioeconomic and political processes and institutions, can contribute to scarcities which bear on those who are already poor, driving inequalities further in terms of gaps between those who can protect themselves and those who cannot; who can grab scarce resources and who cannot. Resource scarcities as felt by particular people and groups are scarcities more of access than of overall availability, and are 'manufactured' as much as natural, including by elites who stand to benefit from them (Mehta 2011). While as Ribot points out 'Vulnerability does not just fall from the sky... The damages associated with climate changes are shaped by the social, political, and economic vulnerabilities of people and societies on the ground' (Ribot, 2009). In the high-rainfall climates of West African forest region, climate change, if experienced as significant at all, is felt mostly in increasingly unpredictable rainy seasons. Yet this, coupled with the squeezing of farmers off most fertile lands by large scale mining and land investments, make rural livelihoods increasingly precarious. This in turn contributes further to the flight to urban areas, and to people's inability to reach health care centres even if they wished to - factors which have in turn fed into the Ebola crisis.

There are also debates and apparent evidence that environmental pressures contribute to conflict and insecurity, and will do further in the future. So we find pervasive and repeated arguments about threatened 'water wars' in the middle east, and that resource pressures underlie African conflicts - from South Sudan to Sierra Leone (Homer-Dixon 1999, Markakis 1998, Bromwich 2008). However relations are complex and there is a real danger of catastrophist narratives that misrepresent environmental change and overlook politicaleconomic causal dynamics in conflict; in short, the ways that inequality dynamics are interlaced too (Gleditsch 1997, Duffield 1994). So we see dynamics linked to resource curses (Collier 2010) - countries with rich resources (minerals, timber) that are easily captured by elites and put into global trading networks, bringing unrest and fuelling conflict, as warlord politics around diamonds did in Sierra Leone and Liberia (Reno 1998).

Crucially, we also see conflict dynamics linked to interventions to deal with environmental change. For instance, today market-led schemes to conserve carbon (through selling credits and offsets), payments for ecosystem services, and conservation are sometimes associated with 'green grabs' that play into a dynamic of dispossession of local livelihoods and resource rights, in favour of private market profit, justified by an interpretation of global environmental need (Fairhead et al 2013). Liberia, Sierra Leone and Guinea offer several examples. These build on a long history of interventions in name of (global) environment misinterpreting the social dynamics of environmental change, and labelling people as resource destroyers, justifying restrictions on them that contribute to inequality, and sometimes conflict. Indeed environmental interventions 
have since colonial times been ways for powerful interests to demobilise threatening populations - whether in restricting the movements of pastoralists, or as in Guinea under Sekou Toure, using state using forest guards to discipline unruly rural areas through fire laws (Fairhead and Leach 1996). And conflict can and does result, as seen in the past and as seen today in resistance to and attacks on forest guards emerging in forest carbon schemes around the world. In this process, local ways of living with environments in socially and ecologically sustainable ways - whether in rural or urban settings, amongst pastoralist, agricultural or forest communities - are often ignored or undermined, along with local knowledge of ecologies and ways to manage them.

There is much talk now of green transformations - restructuring of economies and societies in ways that can generate win-wins. But crucially this cannot just be through markets and technofixes - it will require addressing inequalities, and wellbeing and security questions as locally experienced; and to be effective rather than fuel conflict and inequality further, green transformations will need to be driven by inclusive forms of politics.

\section{Securities}

Ebola spread through countries where war and limited post-conflict recovery still leave their legacy in impoverished infrastructure, capacities and discontent - fuelled by the failure of postconflict recovery processes fully to address the questions of rights and employment that underlay the civil wars in the first place.

Before Ebola hit in 2014, Liberia was recovering slowly from two civil wars stretching over the 1989 period, and Sierra Leone was recovering from a 1991-2002 was that killed more than 50,000 people and displaced more than 2 million. Unsurprisingly, a re-run of war became an early metaphor to describe the spread of Ebola - 'a war with an enemy that we don't see' as a minister in Liberia put it (Ohlheiser 2014), while as the crisis intensified it became feared as likely to precipitate further conflict and state failure (Obaji Ori 2014). Yet the links between the Ebola crisis and war are more than metaphorical, and also causal (Lind and Ndebe 2015). The states in these countries have never been 'weak' or 'fragile' as often depicted by international commentators, but have long been distant from people's everyday lives. This was intensified as the post-cold war structural adjustment period brought about a crisis of the patrimonial state, and it withdrew from education, health and agriculture, enabling rural insurgency to incubate and then flourish in the countries' border areas (Richards 1996). The wars supported massmigration to peri-urban areas and left a legacy of devastated infrastructure and precarious livelihoods, especially for young people (Abramowitz 2014, Hoffmann 2011) - conditions which have fuelled the Ebola crisis and resistance to control efforts.

The post-conflict period has seen attempts to re-build the state, but these have been partial and fragmented, driven by a multiplicity of UN, humanitarian and donor agencies, leaving a situation of uncertainty for many people on the ground. The state has remained something strong and central but distant. Militarised, forcible responses to the Ebola crisis in roadblocks, quarantines and lock-downs recreated memories of war and further eroded trust in public authorities. 
The region's experience highlights the significance of the conflict-security-development nexus in current times, albeit with highly varied, historically-embedded characteristics. We need to be very wary of a securitisation of development, in the sense of a justification primarily in terms of its contributions to national security - averting threats and hazards to national state security interests, usually of rich nations, whether from people (refugees, environmental refugees, terrorists...) or viruses. We also need to beware the intertwining of development with military and defence aims, when this becomes an unfortunate transfer of development spending to defence, or an inappropriate use of military force and styles in development approaches. However, we cannot deny that in a global era, there are important interconnections between development, foreign affairs and the military; the challenge is to re-vision these connections and those with other actors, ideas and practices towards building what might tentatively be called 'inclusive security'.

This is a concept that needs further elaborating and nuancing. It is in some respects akin to notions of 'human security'. But whereas this emphasises security in the achievement of material needs and wellbeing, inclusive security needs to be conceptualised as also very much about political inclusion.

Lack of inclusion in this broadest sense underlies and drives some of the processes that create violence and insecurity, as groups whose claims are unheard or marginalised resort to violence. We have seen this in many civil wars, and it is part of the dynamic of current challenges from extremist groups. Inequalities can contribute to conflict and insecurity, and to difficulties in building workable political settlements - as we have seen from Gaza to Rwanda, from Syria to Sierra Leone - with all the textured complexities of these situations. This is not about narrow relationships between poverty and conflict - an often problematic discourse. It is about more subtle relationships between multiple inequalities and political inclusion/exclusion, and here we find many interlacings.

For instance the Sierra Leonean war was, as Richards (1996) writes, at least in part a rebellion of disenfranchised youth objecting to extreme economic inequality and political exclusion, as urbanised elites pocketed mineral wealth, and they faced lack of jobs and opportunities, and lack of access to land and their own labour in agrarian systems weighted in favour of ex-colonial paramount chiefs. The process of governance decentralisation supported by international donors failed successfully to improve - and in some ways worsened - young people's ability to influence the decisions that affect their lives (Fanthorpe 2005).

Lack of inclusion also drives fear and insecurity in more subtle ways. As we are seeing in the Ebola crisis, longstanding experiences of states that are distant and alien, have been oppressive, or seen to be serving other agendas (whether private enrichment or ethno-regionalisms) can feed suspicion and distrust of motives even when action is taken in avowed common good. The legacy of Guinea's deeply non-inclusive state socialism lives on in people's fear that government outbreak control teams are pumping viruses into their crowded markets. 
Inequality is interlaced with non-inclusive insecurity; people living in highly unequal societies, unless at the top, are unlikely to feel that decisions are serving their interests and are more likely to feel disenfranchised. And horizontal inequalities are deeply interconnected with non-inclusion and insecurity, whether gender-based forms of violence or ethnic marginalisation. (In)security and (un)sustainability are also interlaced, not just because environmental degradation and interventions can create insecurity, but crucially because people need to feel included and secure if to feel, and co-operate in building, a future worth sustaining.

Inclusive security then is multi-dimensional, and what it means will vary for different societies and people. But it certainly encompasses recognition of and support for political enfranchisement; for justice claims, and the building of institutions and mutual trust between authorities and communities. Inclusion implies the ability to influence and be part of the decisions that affect one's life, as an individual or group; and with it respect for rights, beliefs and freedoms.

Inequalities, unsustainabilities, and insecurities thus capture three dimensions of the structural violence that has pervaded many aspects of people's dealings with national and international institutions over the last few decades. Despite the vibrancy of local life, the ways this wider set of forces has played out have reduced a vibrant trading region of the $19^{\text {th }}$ century to one with a set of interlaced inequalities, unsustainabilities and insecurities - sometimes exacerbated by misguided 'development' policies - that have in turn left people vulnerable to this current crisis of biblical proportions.

\section{Implications for development}

These stories also hint, therefore, towards some lessons about what a broader sense of development - one that curbs inequalities, accelerates environmental sustainability, and builds inclusive and secure societies - might look like.

In terms of lessons for development, these stories tell us that humanitarianism is vital but it must be early enough, and appropriate. It tells us that development as aid is important, but that if privatised, fragmented and spent in projects not attuned to local realities and knowledge, it can be deeply unproductive and damaging - as so much around health, environment and rural development in the region has been. More fundamentally, they underline that development is much broader - not just the practices of an aid industry - but pathways of progressive change social, economic and political - that enables people to realise wellbeing and justice in terms that make sense to them. Many actors and forms of agency are part of these processes - and their opposite, negative pathways, or de-development - from international agencies and finance through businesses to forms of grassroots activism, and the many policies and social-politicaleconomic relations that affect all of these, linking local and global.

Tuning up to a world stage, one can argue that we are entering an era where development is recognised, even formally, as a broader set of change processes implicating multiple sets of global-local relations, and the intersection of economic, social, environmental and political 
processes. The emerging post-2015 agenda redefines development not as a north-south issue, but as a matter of mutual responsibilities amongst all people and countries. Development is everywhere, in Brighton as well as Bogota, in Greece as well as Ghana (IDC 2015).

The challenges of curbing inequalities, accelerating environmental sustainability and building inclusive and secure societies are, I suggest, the key ones of our era. With the passage from the MDGs to the SDGs, there is increased recognition of these within the post-2015 development agenda. However, more attention needs to be given to their interlacing and pathways to progressive change that enables people to realize well-being and justice in terms that make sense to them.

2015 is likely to see international agreement on a set of Sustainable Development Goals (SDGs) that apply to all (UNDECA 2015). Many are concerned that these are currently too broad and allencompassing to be useful. Yet as the process to turn 17 goals and 165 targets into a set of meaningful, implementable actions and indicators unfolds over the next year and beyond, we may see the same ills that beset the MDGs - including sectoral silos and a narrow target orientation that fails to influence underlying processes. Nonetheless despite these significant risks, it is worth noting that as aspirational goals, the set of proposed SDGs are different from the MDGs in some key respects. Environmental sustainability recurs and is integrated throughout, rather than being marginalised to a single goal as in the MDGs. There is a goal on inequality, not just poverty, and a goal on peace, security and inclusivity. These were struggled for in the negotiations of the Open Working Group, but their inclusion represents an important set of shifts in the ways that international development is conceived.

Thus the SDGs are moving in some important directions. However if they are to enable societies to be resilient in future to challenges like Ebola, some further key elements are needed. First, they will have to be framed and implemented in national and local settings in ways that make sense to people living these; in short they will need to be not just globally-embedded and universally practised, but also locally embedded. Secondly, the interlacings amongst the separate goals, and their implications, will need to be recognised and addressed more fully; interlacings between the various goals that focus on reducing inequalities, addressing sustainability, and securing peace and good governance.

The United Nations Secretary General recently proposed six cross-cutting 'essential elements' to the post-2015 agenda: '(a) dignity: to end poverty and fight inequality; (b) people: to ensure healthy lives, knowledge and the inclusion of women and children; (c) prosperity: to grow a strong, inclusive and transformative economy; (d) planet: to protect our ecosystems for all societies and our children; (e) justice: to promote safe and peaceful societies and strong institutions; and (f) partnership: to catalyse global solidarity for sustainable development' UN 2014: 1). Meeting the challenges of interlacing, and the experience of the Ebola crisis, do not deny the value of these but add a somewhat reconfigured list that relate not just to principles but also processes - how development happens. These add up together to a vision of development as transformational politics towards addressing interlaced challenges. They imply the need for fresh thinking and action in several arenas. These include several where the Ebola 
crisis has, as I have suggested, revealed current approaches to development to be seriously wanting, and where different approaches could have made a real difference.

One is in relation to global public goods and regulatory capacities. In areas like finance, climate, trade, tax and peace and multilateralism, greater attention and support is badly needed to address inequalities, unsustainability and insecurity. Health, and universal health care access, are recognised as global public goods, yet there is a need to (re)build funding and capabilities, in organisations like the WHO which so woefully failed the early stages of the Ebola outbreak. Capacities need to be there to be drawn down when needed, in responsive ways that build resilience - not in the kind of unseemly scramble for bilateral pledges of funding and personnel when crisis hits that we are seeing with Ebola now. And global public goods need to be built in recognition of common humanity and interconnectedness, not (just) narrow partisan interests as we are seeing now in the struggle to keep Ebola from powerful Northern shores.

A second focus would be the building of inclusive institutions - from the state up and down, and linking formal and informal. The ways that different institutional mixes and interactions can shape different kinds of growth and prosperity needs attention and support. Questions turn not just on how institutions contribute to the satisfaction of material and non-material needs, but also how they contribute to trust, access to justice, and greater equality and security. Working through inclusive institutions in ways that further trust amongst them would have made all the difference in the Ebola case.

A third emphasis is recognition of people-led politics in all their diversity, on the streets and in fields, and combining activism, grassroots ingenuity, challenges and claims. It is community knowledge and practice that is currently driving the most effective Ebola responses. Activism around treatment rights has been vital in other situations of structural violence relating to health - such as around HIV in South Africa. Failure to pick up and work with the pulse of people's real political concerns and modes of expression has underlain past development failures in West Africa and elsewhere, and a new transformational politics needs to rectify this.

But it would be naive and romantic to re-vision development simply in bottom-up terms. Instead, notions of transformational alliances - amongst different interest groups, and amongst actors in public, private and community sectors - may offer ways forward to recognise how progressive change is already happening in some places, and how it might become more widespread. There is much mutual learning that could happen - across and between low income countries, emerging economies, and richer, declining economies on a world stage about how such transformational alliances can be forged, and operate.

Finally, though, serious attention to power and political economy needs to infuse the ways that transformation and alliances are understood and shaped. Structural political economy, coupled with disciplinary power-knowledge, has configured structural violence in places like West Africa. Development lessons will be no more than tokenistic unless they recognise and seek to address these legacies. 


\section{Conclusion}

So can Ebola teach us something? If there is a key lesson to be learned, it is that the Ebola crisis, while originating in a zoonotic disease and health hazard and with desperate health outcomes, primarily represents a crisis of development and political economy. We need to appreciate how anxieties and resistance fly when a distrusted state suddenly intervenes in a response experienced as highly politicised. We need to acknowledge unsettled and ethnicised national politics in post-conflict democracies. We need to appreciate how distrust of foreigners in the region has been fuelled by decades of extractivism and disrespect, and now by private schemes that accrue great material wealth to some while dispossessing others.

The preaching messages that 'Ebola is Real' adorning banners on the rainy streets of Monrovia smack of distant authority. Late in the day, international agencies and national governments started to move towards a more community-engaged approach. As communities learned for themselves about the realities of Ebola, they have started to practice their own safe care, burial and isolation - rather as longer-experienced communities have done for decades in DRC, Uganda and elsewhere (Hewlett and Hewlett 2008).

Will it ultimately prove to have been people's own capacities, and creative solutions as they claim the most basic forms of justice - to live (not die from disease), and to die acceptably, in funerals that are safe from infection but also enable respect for relatives living and in the afterlife - that ended this epidemic? Will the world's resources be harnessed to support these effectively - and to re-build systems that can provide greater resilience into the future? And will all of us then take the time to reflect on lessons for development more broadly - a development where inequality, unsustainability, insecurity and inappropriate 'development' interventions can interlace to produce conditions of structural violence that let crisis loose, and which need to be turned round if development - more equal, sustainable, and secure societies, for people - is to unfold?

\section{References}

Abby, P. 2014, "Eight dead in attack on Ebola team in Guinea. 'Killed in cold blood."'. The Washington Post. 18 September 2014.

Abramowitz, S. 2014. Searching for Normal in the Wake of the Liberian War. University of Pennsylvania Press.

Abramowitz, S., 2014, 'How the Liberian health sector became a vector for Ebola', 7 October 2014, Cultural Anthropology Online, <http://www.culanth.org/fieldsights/598-how-theliberian-health-sector-became-a-vector-for-ebola> (8 October 2014). 
Allouche, J., 2015, Ebola and Extractive Industry. IDS Practice Paper in Brief 21. Brighton: Institute of Development Studies.

Arauco, Veronica Paz, Haris Gazdar, Paula Hevia-Pacheco, Naila Kabeer, Amanda Lenhardt, Syeda Quratulain Masood, Haider Naqvi, Nandini Nayak, Andrew Norton, Nidhi Sadana Sabharwal, Elisa Scalise, Andrew Shepherd, Deepak Thapa, Sukhadeo Thorat, D. Hien Tran, Leandro Vergara-Camus, Tassew Woldehanna, Chiara Mariotti, 2014, Strengthening social justice to address intersecting inequalities post-2015. ODI Report. London: Overseas Development Institute.

Bausch, D. G., \& Schwarz, L. (2014). Outbreak of Ebola virus disease in Guinea: where ecology meets economy. PLoS neglected tropical diseases, 8(7), e3056.

Breen, L. 2014. 'Fighting Ebola, Liberia's “Invisible Rebel".' Washington Post. August 29't , 2014.

Baland, J-M., P.Bardhan and S. Samuel Bowles, 2006, Inequality, Cooperation, and Environmental Sustainability. Princeton: Princeton University Press.

BBC 2015 Ebola crisis: Oxfam calls for recovery Marshall Plan, BBC News 27 January 2015, http://www.bbc.co.uk/news/uk-30995631, Accessed February 82015

Bolten, Catherine E., 2014, "Articulating the Invisible: Ebola Beyond Witchcraft in Sierra Leone." Fieldsights - Hot Spots, Cultural Anthropology Online, October 07, 2014, http://www.culanth.org/fieldsights/596-articulating-the-invisible-ebola-beyondwitchcraft-in-sierra-leone

Boseley, S., 2014, 'Ebola: government cuts to the WHO aided delays in dealing with outbreak', The Guardian, 9 October 2014, <http://www.theguardian.com/world/2014/oct/09/ebolawho-government-cuts-delays-in-dealing-with-outbreak> (15 October 2014).

Bromwich, B., 2008, Environmental degradation and conflict in Darfur: implications for peace and recovery. Humanitarian Exchange Magazine 39: 22-27.

Clower, R.W., G. Dalton, M. Harwitz and A.A. Walters, 1966, Growth without Development: an Economic Survey of Liberia. Chicago: Northwestern University Press.

Collier, P., 2010, The Political Economy of Natural Resources, Social Research Vol 77 : No 4 : Winter 2010, 1105-1132

Davies, Victor A.B., 2012, The political economy of government revenues in post-conflict resource-rich Africa: Liberia and Sierra Leone, National Bureau of Economic Research Working Paper 18539, Cambridge, MA, November 
Dowden, R., 2014, Little evidence of 'Africa Rising' in Ibrahim Index of African Governance, African Arguments, October, 1, 2014 http://africanarguments.org/2014/10/01/africas-newnumbers-revealing-and-intriguing-by-richard-dowden/

Duffield, M., 1994, "The Political Economy of Internal War: Asset Transfer, Complex Emergencies and International Aid," in Joanna McRae and Anthony Zwi (eds.), War and Hunger:

Rethinking International Responses (London: Zed, 1994)

Dry, S. and M. Leach (eds), 2010, Epidemics: Science, governance and social justice. London: Earthscan.

Epstein, H., 2014, "Ebola in Liberia: An Epidemic of Rumors", The New York Review of Books.

Fairhead, J. and M. Leach, 1996, Misreading the African Landscape: Society and Ecology in a Forest-Savanna Mosaic. Cambridge: Cambridge University Press.

Fairhead, J. and M. Leach, 1998, Reframing Deforestation: Global Analysis and Local Realities Studies in West Africa. London: Routledge.

Fairhead, J. and M. Leach, 2003, Science, Society and Power: Environmental Knowledge and Policy in West Africa and the Caribbean. Cambridge: Cambridge University Press.

Fairhead, J., T. Geysbeek, S. Holsoe and M. Leach, 2003, African-American Exploration in West Africa: Four nineteenth century diaries. Bloomington: Indiana University Press.

Fairhead, J., M. Leach and I. Scoones (eds), 2013, Green Grabbing: A New Appropriation of Nature? London: Routledge.

Farmer, P., 2003. Pathologies of power: Health, human rights, and the new war on the poor. Berkeley: University of California Press.

Farmer, P., 2004, 'An Anthropology of Structural Violence', Current Anthropology Volume 45, Number 3, June 2004

Farmer, P., 2014, Ebola: Countries Need 'Staff, Stuff, and Systems', Partners in Health. http://www.pih.org/blog/for-ebola-countries-need-tools-to-treat-patients-in-theircommunities. Accessed February 82015.

Faul, M., 2014, The village of Meliandou: Guinea's ground zero. Associated Press http://en.radiovaticana.va/news/2014/12/10/the village of meliandou guineas ground zero ebola /1114310, accessed February 82015.

Fanthorpe, R.,2006, On the limits of liberal peace: Chiefs and democratic decentralization in post-war Sierra Leone. African Affairs 05(418): 27-49. 
Ferme, Mariane C. 2001, The Underneath of Things. Violence, History, and the Everyday in Sierra Leone. Berkeley: The University of California Press.

Ferme, Mariane C. 2014, 'Hospital diaries: experiences with public health in Sierra Leone', 7 October 2014, Cultural Anthropology Online, <http://www.culanth.org/fieldsights/591hospital-diaries-experiences-with-public-health-in-sierra-leone> (8 October 2014).

Fyfe, C., 1962, A History of Sierra Leone. London, 1962.

Galtung, J., 'Violence, peace, and peace research', Journal of Peace Research, 6/3 (1969), pp.16791.

Gilens, M. and B.I. Page, 2014, Testing Theories of American Politics: Elites, Interest Groups, and Average Citizens Perspectives on Politics, Volume 12, Issue 03: pp 564-581.

Gilligan, J., 1997, Violence: Reflections on a National Epidemic. New York: Random House.

Gordts, E. 2014. 'Top Liberian official warns Ebola crisis may plunge the country back into confict.' Huffington Post. September 24 ${ }^{\text {th }}, 2014$.

Gostin, L.O. and Eric A. Friedman, 'Ebola: a crisis in global health leadership', The Lancet, 384/9951 (2014), pp.1323-25.

Green, T., 2014, The Rise of the Trans-Atlantic Slave Trade in Western Africa, 1300-1589, Cambridge University Press

Gleditsch, N.P. (ed.), 1997, Conflict and the Environment. Dordrecht: Kluwer Academic.

Grundy, T. 2014, Tradition Of Kissing, Touching Corpses May Contribute To Spread Of Ebola, Experts Say Huffington Post, September 282014 http://www.huffingtonpost.com/2014/09/28/kissing-corpses-ebola n 5888838.html, accessed 8 February 2015

Hewlett, B. and B. Hewlett, 2008, Ebola, Culture and Politics: The Anthropology of an Emerging Disease. Belmont, CA: Thomson Wadsworth.

Hoffman, D. 2011. The War Machines: Young Men and Violence in Sierra Leone and Liberia. Duke University Press.

Homer-Dixon, T., 1999, Environment, Scarcity and Violence. Princeton: Princeton University Press. 
IDC 2015, 'The Future of UK Development Cooperation: Phase 2: Beyond Aid'. Tenth Report of Session 2014-15, House of Commons International Development Committee. London: UK Government.

Leach, M., 1994, Rainforest Relations: Gender and resource use among the Mende of Gola, Sierra Leone. Edinburgh: Edinburgh University Press.

Leach, M., I. Scoones and A. Stirling, 2010, Dynamic Sustainabilities: Technology, Environment, Social Justice. London: Routledge.

Leach, M. And J. Fairhead, 2007, Vaccine Anxieties: Global Science, Child Health and Society. London: Earthscan.

Leach, M., K. Raworth and J. Rockström, 2013, 'Between social and planetary boundaries: Navigating pathways in the safe and just space for humanity', Introductory keynote chapter, World Social Science Report. Paris: International Social Science Council.

Leach, Melissa, James Fairhead, Dominique Millimouno, and Alpha Ahmadou Diallo, 2008, 'New therapeutic landscapes in Africa: parental categories and practices in seeking infant health in the Republic of Guinea', Social Science \& Medicine, 66/10: 2157-67.

Lind, J. and J. Ndebe, 2015, Return of the Rebel: Legacies of War and Reconstruction in West Africa's Ebola Epidemic. IDS Practice Paper in Brief 19. Brighton: Institute of Development Studies.

MSF 2014, 'Ebola in West Africa: epidemic requires massive deployment of resources', Médecins Sans Frontières, 23 June 2014, <http://www.msf.org/article/ebola-west-africa-epidemicrequires-massive-deployment-resources> (15 October 2014).

Markakis, J., 1998, Resource Conflict in the Horn of Africa. London: Sage.

Mehta, L. (ed), 2011, The Limits to Scarcity. London: Routledge.

Maconachie, R., 2008, New agricultural frontiers in post-conflict Sierra Leone? Exploring institutional challenges for wetland management in the Eastern Province. The Journal of Modern African Studies 46(2): 235-266.

Maconachie, R., 2012, Artisanal diamond mining and rural livelihoods in Sierra Leone: continuity, change and challenges. In: Van Bockstael, S. and Vlassenroot, K., eds. A Farmer's Best Friend? Artisanal diamond mining and rural change in West and Central Africa. Ghent: Academia Press, pp. 11-32. 
McCoy, T., 'How deforestation shares the blame for the Ebola epidemic', The Washington Post, 8 July 2014, <http://www.washingtonpost.com/news/morning-mix/wp/2014/07/08/howdeforestation-and-human-activity-could-be-to-blame-for-the-ebola-pandemic/> (15 October 2014).

McGovern, M., 2012, Unmasking the State: Making Guinea Modern. Chicago: Chicago University Press.

Obaji Ori, K. 2014. 'Liberia: Ebola threatens statehood success, post civil war.' The Africa Report. October 14 ${ }^{\text {th }}, 2014$.

Ostrom, E., 1990, Governing the Commons: The Evolution of Institutions for Collective Action. Cambridge: Cambridge University Press.

Oxfam, 2014, Even it Up: Time to end extreme inequality. Oxford: Oxfam

Pearce, F., 2012, The Landgrabbers: the new fight over who owns the earth. London: Transworld Publishers.

Piketty, T., 2014, Capital in the $21^{\text {st }}$ Century. Boston: Harvard.

Quammen, D. 2014, Ebola: The natural and human history of a deadly virus. New York: W.W. Norton and Co.

Reno, W., 1998, Warlord Politics and African States. Boulder, Colo.: Lynne Rienner.

Reno, W., 1995, Corruption and State Politics in Sierra Leone. New York: Cambridge University Press.

Ribot, Jesse C. 2009, Vulnerability does not just Fall from the Sky: Toward Multi-scale Pro-poor Climate Policy, in Robin Mearns and Andrew Norton (eds.), Social Dimensions of Climate Change: Equity and Vulnerability in a Warming World. Washington, DC: The World Bank.

Richards, P., Fighting for the rain forest: war, youth and resources in Sierra Leone. London: International African Institute.

Richards, Paul, Joseph Amara, Mariane C Ferme, Prince Kamara, Esther Mokuwa, Amara Idara Sheriff, Roland Suluku, and Maarten Voors, 2014, Social pathways for Ebola Virus Disease in rural Sierra Leone, and some implications for containment., PLOS Neglected Tropical Diseases October 2014

Rockström, J., Steffen, W., Noone, K., Persson, Å., Chapin, III, F. S., Lambin, E. F., Lenton, T. M., Scheffer, M., Folke, C., Schellnhuber, H. J., Nykvist, B., de Wit, C. A., Hughes, T., van der Leeuw, S., Rodhe, H., Sörlin, S., Snyder, P. K., Costanza, R., Svedin, U., Falkenmark, M., 
Karlberg, L., Corell, R. W., Fabry, V. J., Hansen, J., Walker, B., Liverman, D., Richardson, K., Crutzen, P. and Foley, J. A. (2009) 'A safe operating space for humanity', Nature, vol 461, pp472-475

Saliou Samb and Alphonso Toweh, 'Beware of bats: Guinea issues bushmeat warning after Ebola outbreak', Reuters, 27 March 2014, <http://www.reuters.com/article/2014/03/27/usebola-bushmeat-idUSBREA2Q19N20140327> (13 October 2014).

Schoepp, R., Cynthia Rossi, Sheik H. Khan, Augustine Goba, and Joseph Fair, 'Undiagnosed acute viral febrile illnesses, Sierra Leone', Emerging Infectious Diseases, 20/7 (2014), <http://wwwnc.cdc.gov/eid/article/20/7/13-1265_article> (1 November 2014)

Shaw, R., 2014, Memories of the Slave Trade: Ritual and the historical imagination in Sierra Leone. Chicago: Chicago University Press.

Stewart, F.,2002, Horizontal Inequalities: A Neglected Dimension of Development. QEH Working Paper Series - QEHWPS81. Oxford: Queen Elizabeth House.

Steffen, Will, Katherine Richardson, Johan Rockström, Sarah E. Cornell, Ingo Fetzer, Elena M. Bennett, R. Biggs, Stephen R. Carpenter, Wim de Vries, Cynthia A. de Wit, Carl Folke, Dieter Gerten, Jens Heinke, Georgina M. Mace, Linn M. Persson, Veerabhadran Ramanathan, B. Reyers,, Sverker Sörlin, 2015, Planetary boundaries: Guiding human development on a changing planet, Science, Published online January 152015.

Tran, M., 2013, Sierra Leone's smallholder farmers 'worse off' after large land deals, http://www.theguardian.com/global-development/2013/jul/26/sierra-leone-farmersland-deals, Accessed February 82015.

UN 2014, The road to dignity by 2030: ending poverty, transforming all lives and protecting the planet. Synthesis report of the Secretary-General on the post-2015 sustainable development agenda. United Nations General Assembly Sixty-ninth session Agenda items 13 (a) and 115. New York: United Nations.

UNDECA 2015, Sustainable Development Goals. United Nations Department of Economic and Social Affairs. https://sustainabledevelopment.un.org/topics/sustainabledevelopmentgoals. Accessed 12 February 2015.

Wald, P., 2008, Contagious: cultures, carriers, and the outbreak narrative Durham, NC: Duke University Press.

Waldman, L., 2015, Urbanisation, peri-urban growth and zoonotic disease. IDS Practice Paper in Brief 22. Brighton: Institute of Development Studies. 
WHO 2014a, Experimental therapies: growing interest in the use of whole blood or plasma from recovered Ebola patients (convalescent therapies), Ebola situation assessment - 26 September 2014, http://www.who.int/mediacentre/news/ebola/26-september2014/en/, accessed February 82015

WHO 2014b 'WHO statement on the meeting of the International Health Regulations Emergency Committee regarding the 2014 Ebola outbreak in West Africa', 8 August 2014, World Health Organization, <http://www.who.int/mediacentre/news/statements/2014/ebola20140808/en/ > (13 October 2014).

WHO Ebola Response Team 2014, Ebola virus disease in West Africa--the first 9 months of the epidemic and forward projections. N Engl J Med. 2014 Oct 16;371(16):1481-95. doi: 10.1056/NEJMoa1411100. Epub 2014 Sep 22.

WHO 2015, Ebola Situation Report - 9 April 2015 http://apps.who.int/gho/data/view.ebolasitrep.ebola-summary-latest?lang=en, World Health Organisation, accessed April 10 2015

Wilkinson, A. and M. Leach, 2014, Briefing: Ebola - myths, realities and structural violence, African Affairs Advance Access published December 4, 2014, http://afraf.oxfordjournals.org/content/early/2014/12/04/afraf.adu080.full.pdf?papetoc

Wilkinson, R. and K. Pickett, 2009, The Spirit Level: Why equality is better for everyone. London: Penguin.

World Bank, 2015, Bottom 20\% incomes, http://data.worldbank.org/indicator/SI.DST.FRST.20, accessed February 82015. 